Research article

urn:1sid:zoobank.org:pub:935D0B09-0508-4771-9575-28C1FE761383

\title{
Siphonophoridae from Brazilian Amazonia Part 1 - The genus Columbianum Verhoeff, 1941 (Diplopoda, Siphonophorida)
}

\author{
Helen J. READ ${ }^{1,{ }^{*}}$ \& Henrik ENGHOFF ${ }^{2}$ \\ ${ }^{1} 2$ Egypt Wood Cottages, Farnham Common, Bucks, SL2 3LE UK. \\ ${ }^{2}$ Natural History Museum of Denmark, University of Copenhagen, \\ Universitetsparken 15, DK-2100 Copenhagen Ø, Denmark. \\ *Corresponding author: helen@helen-read.co.uk \\ 2Email:henghoff@snm.ku.dk \\ ${ }^{1}$ urn:1sid:zoobank.org:author:30F92B0D-B214-44AA-9508-C0042D6BB628 \\ ${ }^{2}$ urn:1sid:zoobank.org:author:FB09A817-000D-43C3-BCC4-2BC1E5373635
}

\begin{abstract}
A large sample of Siphonophoridae from Brazil was studied; two morphological groups could be distinguished. Here species considered to be from the genus Columbianum Verhoeff, 1941 are examined in detail. The genus is known from Central and South America (Guatemala, Panama, Honduras, Guiana, Colombia, Peru and Brazil) and is characterised by a clear demarcation between head and rostrum in combination with long antennae, clearly surpassing the tip of the rostrum. A list of previously described species considered to belong to the genus is given; three new species are described: C. major sp. nov. has a large body size and a small head, C. nahvalr sp. nov. has a particularly pronounced domed head and a more castellated appearance to the body, $C$. adisi sp. nov. has a small body size and a very characteristic hind margin to the pleurites. Variation in the state of preservation of specimens hinders a diagnosis, but the examination of the accessory claw and details of the metazonital limbus and pleurite edges are helpful. Unusually for Diplopoda, the male gonopods are not very useful for identification. Ecological comments are given for each new species, one of which, C. adisi sp. nov., is from the seasonally flooded forest and appears to avoid inundation by climbing trees.
\end{abstract}

Keywords. Siphonophorida, Siphonophoridae, Brazil, Amazonia.

Read H.J. \& Enghoff H. 2018. Siphonophoridae from Brazilian Amazonia Part 1 - The genus Columbianum Verhoeff, 1941 (Diplopoda, Siphonophorida). European Journal of Taxonomy 477: 1-23.

https://doi.org/10.5852/ejt.2018.477

\section{Introduction}

The order Siphonophorida is one of the most poorly studied of all the Diplopoda. As a consequence, there are a large number of species described on the basis of single specimens, sometimes a female or juvenile. Most species have been assigned to the nominal genus Siphonophora Brandt, 1837. Unlike many other groups of Diplopoda the male gonopods are quite simple and do not appear to vary substantially between different species. Attempts to clarify the situation were made by Verhoeff (1941) and Attems (1951) who 
differed substantially in their understanding of the order. A recent catalogue by Jeekel (2001) listed all known species and acknowledged that there were probably many synonymies. The distinction between the two families, Siphonophoridae and Siphonorhinidae, seems to be relatively clearly and consistently defined, but the classification within the families, especially the Siphonophoridae, remains a muddle.

\section{A taxonomist's nightmare?}

Many of the characters used by previous authors were found either not to vary between different morphotypes or to vary between individuals that were clearly the same species or even within the same individual (Read \& Enghoff 2009). The gonopods are difficult to study; in some specimens they appear long and protrude like walking legs, in others they are tightly pressed together and contracted close to the trunk. This variation is due to the state of preservation of the specimen and not due to differences between species, but the gonopods can appear very different. In addition, the gonopod block always separates between the anterior and posterior gonopods during dissection. Attempts to divide it in the midline generally fail and result in individually separated gonopods which are very small. Determining lateral and mesal views of anterior and posterior gonopods is then very difficult. Where possible several views of the gonopods have been illustrated, but this has not been possible for all species.

Differences of preservation can also make the body trunk appear quite different. A contracted specimen appears to be more or less 'smooth' dorsally; in a more relaxed one the pro- and metazonites can be distinguished clearly, and in a lateral view the body may appear to be 'castellated' dorsally. For the same reason, measuring the body height proved unreliable; depending on the state of preservation, the pleurites might be entirely visible in lateral view, or entirely invisible. For this reason the body width was used as a measurement of overall body size, together with the length.

Notwithstanding these issues two groups of species could be clearly distinguished by the rostrum shape, and this paper concerns a group of three with a clear distinction between the head and rostrum rather than a gradual transition. See below, under 'Genus Columbianum Verhoeff, 1941', for a full list of other characters that unite this group.

\section{Species previously found in the region}

At the present state of knowledge we have no idea of how widespread individual species of Siphonophoridae are. We are therefore aware that our focus on previously described species from the Neotropial region, especially Brazil, is a weak point. Nevertheless, we think that in order to make some progress, this limitation is warranted.

Three species of Siphonophoridae have been described previously from Brazil, Siphonophora pubescens Schubart, 1947, Rhinosiphora hebetunguis Attems, 1951 and Siphonophora paulistus [recte: paulista] Schubart, 1945. Illustrations of the first two species show clear gradual head shapes; the types of $R$. hebetunguis (Naturhistorisches Museum Wien) were also examined which showed that the specimens have heads unlike those of the three species described here. The head of $S$. paulista, however, was described by Schubart (1945) as 'arredondada' [rounded] and the illustration looks similar to the species treated here. The rather poor description was made from a single damaged female and some juveniles, so many of the features are difficult to check. The collum was described as oval and is illustrated with a straight anterior edge, very different in shape to what we have seen in Brazilian specimens. In conclusion, it cannot be ruled out that one (or both) of the two smaller species described here are actually S. paulista, but the shape of the collum and the fact that the location (Monte Alegre) is a long way away from Amazonia suggest that this is a different species. Comparison with the holotype of S. paulista will probably not be helpful, because the types consist of juveniles and a damaged female. 


\section{History of Columbianum Verhoeff, 1941}

The division of the Siphonophoridae into two groups based on head shape has been suggested previously by Verhoeff (1941). Some genera were described by Verhoeff as having a beak $1 / 3-4 / 5$ the length of the head and separate from it, and the other group as having the beak longer than the head and not separate from it. This separation was subsequently criticised by Carl (1944) and Attems (1951). Attems (1951) pointed out that all intermediate stages are possible. Verhoeff (1941) erected three genera for his 'abrupt headed group', Chamberlinium Verhoeff, 1941, Columbiozonium Verhoeff, 1941, and Columbianum Verhoeff, 1941. Of these Chamberlinium was invalidly proposed (no type species designated, Jeekel 1971) and Columbiozonium is regarded a junior synonym of Columbianum because the type species of both nominal genera are very similar, 'indeed one may wonder if really two species are involved' (Jeekel 2001).

Jeekel (2001) listed four species of Columbianum, C. andecola (Kraus, 1954), and C. porcullae (Kraus, 1954) both from Peru, as well as C. gracilicorne (Carl, 1914), and C. pearsei (Chamberlin, 1923) from Colombia. Jeekel (2001) noted that gracilicorne and pearsei are very similar and may be synonymous, both having the same distinct pleurite shape. Illustrations of the heads of all these species show a clear demarcation between the head and the rostrum, and all have a very round, domed head in lateral view, although in porcullae this is rather less so. All have antennae surpassing the end of the rostrum by a substantial amount.

Chamberlinium was erected by Verhoeff (1941) for Siphonophora telana and S. fallens, both described by Chamberlin (1922) from Central America, and for S. corynetes Chamberlin, 1923 from British Guiana. All three of these species have clearly abrupt rostrums, and the antennae are much longer than the rostrum. We therefore suggest that these three species should be included in the genus Columbianum, too.

Comparing the illustrations of other Siphonophoridae reveals several other species with a similar head shape and with very long antennae relative to the rostrum, all from South and Central America. Siphonophora aviceps Loomis, 1961, from Panama, was described as being "related to S. telana" being different in size, segment number and details of the antennae, although the latter was described from a single female. Siphonophora aviceps was transferred to the genus Siphonacme Cook \& Loomis, 1928 by Jeekel (2001) based on the similarity of its anterior gonopods with those of, e.g., Siphonacme lyttoni Cook \& Loomis, 1928; we think, however, that S. aviceps is better placed in Columbianum. We examined two female type specimens of Siphonophora meinerti Silvestri, 1898 (in NHMD) and found this species to be a typical Columbianum; see above concerning S. paulista. Jeekel (2001) has already placed C. andecola (Kraus, 1957) in the genus Columbianum and we agree with this interpretation based on the original description. Siphonophora monzonica Kraus, 1960, from Peru, was listed by Jeekel (2001) as resembling Columbianum, and the description supports this placement. Siphonophora corynetes Chamberlin, 1923, S. fallens Chamberlin 1922, S. progressor Chamberlin, 1922, S. relicta Chamberlin, 1923, and S. telana Chamberlin, 1922 all appear to show the typical Columbianum head shape, according to their original descriptions.

Three further species may also be worthy of consideration, S. platops Loomis, 1941, S. pseustes Chamberlin, 1923, and S. lafloridae Kraus, 1955, but their descriptions and illustrations are not quite clear enough to be certain. For all those species where the pleurite shape has been described, it appears to be sinuous or bilobed ventrally and with a 'step' or 'spike' in the posterior margin, at least towards the anterior end of the body. The accessory claw is rarely mentioned by previous authors, nor are any details of the sculpturing or limbus.

The type species of Siphonophora is S. portoricensis Brandt, 1837, which was redescribed by Shelley (1996). The head shape of this species is clearly gradual. Supposing that at least some of the characters 
described above for the abrupt rostrum species in the Brazilian collection we have studied hold true for those others with abrupt heads, but not for those with more gradual head shape, it seems reasonable to group them as a separate genus, at least until further work is carried out. It is here suggested that Columbianum is a valid and clearly separate genus from Siphonophora and includes the above species.

Three species found in the collection from Brazil appear to belong to the genus Columbianum, according to the above definition.

\section{Material and methods}

An exceptionally large collection of Siphonophoridae was gathered over many years in the course of an extensive study of the invertebrates of the Amazonian region of Brazil near to Manaus by the late Joachim Adis and colleagues (see Wolf \& Adis 1992 for a map showing the collecting localities mentioned in the text). In addition to numbering 300 individuals, this collection is especially interesting because several different sampling methods were used, including trapping, thus the collection is likely to include a range of different developmental stages.

A total of 294 individuals were studied; a small number were too damaged. Specimens were observed under a light microscope (Nikon SMZ 2B) and a range of characters described and measured. Initially, a full list of all characters were noted for each individual concerned. In addition, various measurements were made. After looking in detail at a relatively small number of specimens, the list of characters was reduced slightly as some (measurements in particular) proved unreliable, and some characteristics were found not to vary at all between the different individuals studied.

In addition to work under the light microscope, SEM preparations were made for all morphospecies although lack of material for one meant it was only possible to observe midbody segments. Wherever possible, SEM studies were used to observe limbus of the tergite, limbus of the pleurites, bases of walking legs, tarsal claws and accessory claws of walking legs, setae and tubercles of the tergites and pleurites, the zone between the prozonite and the metazonite, spiracles, ozopores, the male gonopods, the head and rostrum area and the collum in dorsal view. The SEM used was a JEOL JSM-6335F.

The characters used in the species descriptions below are as follows:

Body length: estimated, using a squared microscope graticule, from tip of head to tip of telson following the approximate lateral midbody line. Length varies considerably in these specimens, depending on the state of preservation and the relative degree of relaxedness of the membranes between the body rings.

Body width: estimated, using a squared microscope graticule, as maximum width of specimen when viewed dorsally.

Number of podous tergites including the collum.

Number of apodous tergites: those discernible between the podous tergites and the telson. In some colobognath millipedes it can be difficult to determine the number of apodous tergites (David \& Couret 1983), but generally this was not a problem in the current collection. The current state of knowledge regarding the anamorphosis of colobognath millipedes was summarised by Enghoff et al. (1993). We use the terms 'podous tergites' and 'apodous tergites' following these authors although strictly speaking a tergite cannot carry legs. 'Body ring' or just 'ring' are used to denote an apparent (diplo)segment consisting of tergite, pleurites and sternum/sterna.

Description of body shape: notes were made of any variation in body shape anteriorly or posteriorly. 
Body colour: notes were made, but, due to the collection methods for most of the specimens, this feature is not particularly helpful in the present study. Colour patterns in life and for those killed by different methods, such as in picric acid, may have been missed.

Description of head: this included shape in dorsal and lateral views, shape of rostrum, abundance and distribution of setae and tubercles.

Head measurements: initially a wide range of measurements were attempted for the head. Due to the variation in size of the body due to the state of preservation, the size of the head was considered as a surrogate of overall size. However, the head was frequently largely covered by the collum and total length and maximum width were generally not measurable. Two measurements were considered reliable, the width between the antennal sockets and the length of the rostrum from the anterior edge of the antennal socket to the tip.

Antennae: the length was initially measured in situ and the number of visible segments counted. This varied enormously from one specimen to the next in the same vial as the antennae can appear very relaxed and long with all segments visible, or very contracted with each antennomere telescoped into the previous with the last two segments invisible. For a small number of individuals an antenna was removed, slide mounted, and the dorsal length of each antennomere was measured together with its width of the widest point. The total antennal length was the sum of the length of all antennomeres. General descriptions of antennal length have been made, and an estimate of how much the antennae surpass the rostrum tip relative to the length of the rostrum (from base to tip) was made without accurate measurements taken. Figures quoted in relation to body width are from detached and slide mounted antennae. The length of the antenna is given as a percentage of the body width. The presence of antennal pits and sensilla was noted.

Collum: the shape of the anterior edge was described, as well as the relative abundance of setae and tubercles, and the mid dorsal width.

Tergum 2 (i.e., the first after the collum): this was described.

Midbody rings: descriptions were made of the tergites and pleurites, the pro- and metazonites, and the area between them. These included the overall shape, pilosity and distribution of tubercles and the relative mid-dorsal width of the pro- and metazonite calculated as prozonite/metazonite to give a ratio (giving an impression of the degree of 'castellation' due to metatergal ridges). The maximum length of a midbody tergal seta was measured. An attempt to describe the limbus (Schmidt 1962) of the tergite and the hind edge of the pleurite was made, but in reality this required SEM techniques.

Midbody legs: for selected specimens a midbody leg was slide mounted and the dorsal length and maximum width of each podomere from the prefemur to the tarsus measured (Enghoff 1982). Total leg length was then compared with the body width; the relative length and width of each podomere could be observed and any features of the claw and accessory claw noted. Measurements of the accessory claw relative to the tarsal claw quoted in descriptions are from these specimens, additional general comments were made from SEM studies.

Ozopores: the overall shape was noted, as well as the presence of protuberances and the ring number of the first and last pore.

Telson: shape and setation were described and measurements made of the width and length. Anything of note regarding the anal valves and ventral scale was recorded. 
Female sex organs: protruding vulvae were only noted in a small number of individuals, but were not studied in detail.

Male sex organs: gonopods were drawn in situ and also dissected, and mounted for more detailed drawings. We examined gonopods of several specimens using SEM, but this provided no useful information (cf. introduction) and we have not included SEM images of gonopods. Legs 1-8 were also checked.

Initially, the individuals were assigned to different morphospecies. Subsequently, the literature was searched for comparable species.

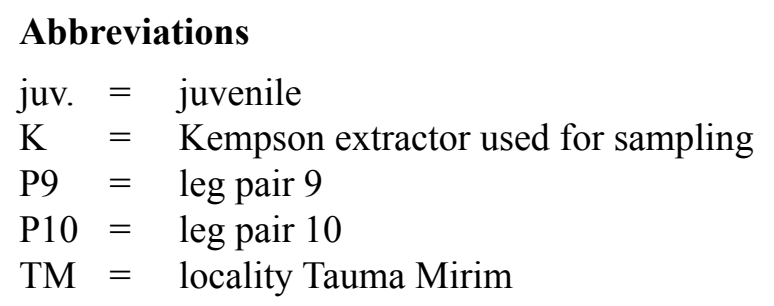

\title{
Repositories
}

INPA = Instituto Nacional de Pesquisas da Amazônia, Manaus, Brazil

NHMD $=$ Natural History Museum of Denmark, University of Copenhagen, Denmark

NHMUK $=$ The Natural History Museum, London, UK

ZMUM $=$ Zoological Museum of the State University of Moscow, Russia

\section{Results}

\section{Taxonomy}

\author{
Class Diplopoda de Blainville in Gervais, 1844 \\ Order Siphonophorida Newport, 1844 \\ Family Siphonophoridae Cook, 1895
}

Genus Columbianum Verhoeff, 1941

Columbianum Verhoeff, 1941: 216. Type species: Siphonophora gracilicornis Carl, 1914, by monotypy. Columbiozonium Verhoeff, 1941: 216. Type species: Siphonophora pearsei Chamberlin, 1923, by monotypy, synonymized by Jeekel (2001).

[Chamberlinium Verhoeff, 1941: 215. Invalidly proposed without a type species.]

\section{Diagnostic notes}

As understood here Columbianum, is a Central and South American genus with a clear demarcation between the head and rostrum.

Other characters that may help to distinguish this genus are:

- a relatively short rostrum relative to the head length. Rostrum more or less parallel-sided and much narrower than head. Rostrum straight or slightly downcurved.

- relatively long antennae clearly reaching well beyond the tip of the rostrum.

- the anterior margin of the collum appearing to be strongly curved posteriorly, but under SEM this can be seen to be mostly due to a thin, non-tuberculate region bordering on the concavity and contrasting 
with a thickened region with tubercles. This can usually be seen under light microscope when looking carefully.

- a short tergite 2 which is less than half, sometimes only one third, of the length of the collum.

- pleurites in those species examined have a sinuous ventral margin, at least on anterior pleurites, to accommodate the coxae, and often a stepped posterior margin, sometimes with a distinct spike.

- constriction between pro- and metazonite with a single line of setae.

- metazonites slightly larger than prozonites, giving a more or less pronounced ridged effect, at least anteriorly on the body.

- short tergal setae.

- a crenulated limbus on posterior margin of tergites.

- hind edge of pleurites crenulated or strongly serrate when seen from 'inside'.

- sensory fields on antennomeres 5 and 6.

- the gonopods appear to conform to the general siphonophorid plan and are quite simple. The anterior gonopods are robust and with abundant spines, bent sharply anteriad and frequently with an additional projection on the mesal side. The apical segment of the posterior gonopods is long and thin, frequently with a small spine towards the base and with a web-like or bifurcated tip.

- the accessory claws of the three species examined from Brazil are all very large and robust and arising from the anterior side of the claw. They are visible under light microscope at least on the legs in the anterior half of the body but not on the first few leg pairs. Claws hence almost appearing to be double.

These characters are not necessarily apomorphies, nor diagnostic generic features, because the extent to which they occur in previously described species is not yet known.

The distinguishing features between the three new species are outlined below in the species descriptions. In addition, a plot of body width against number of podous tergites was made, and three clear groups can be seen. That for the males is given in Fig. 1A and for the females in Fig. 1B.

\section{Tentative list of species included in Columbianum}

Columbianum andecola (Kraus, 1954) - Peru

Columbianum aviceps (Loomis, 1961) comb. nov. ex Siphonophora - Panama (perhaps synonymous with telana)

Columbianum corynetes (Chamberlin, 1923) comb. nov. ex Siphonophora - Guiana

Columbianum fallens (Chamberlin, 1922) comb. nov. ex Siphonophora - Guatemala and Panama

Columbianum gracilicorne (Carl, 1914) - Colombia

Columbianum meinerti (Silvestri, 1898) comb. nov. ex Siphonophora - Venezuela

Columbianum monzonica (Kraus, 1960) comb. nov. ex Siphonophora - Peru

Columbianum paulistum (Schubart, 1945) comb. nov. ex Siphonophora-Brazil

Columbianum pearsei (Chamberlin, 1923) - Colombia (perhaps synonymous with gracilicorne)

Columbianum porcullae (Kraus, 1954) - Peru

Columbianum progressor (Chamberlin, 1922) comb. nov. ex Siphonophora - Honduras

Columbianum relicta (Chamberlin, 1923) comb. nov. ex Siphonophora - Guiana

Columbianum telana (Chamberlin, 1922) comb. nov. ex Siphonophora - Honduras

\section{Dubiously included species}

Siphonophora platops Loomis, 1941 - Dominican Republic

Siphonophora pseustes Chamberlin, 1923 - Mexico

Siphonophora lafloridae Kraus, 1955 - Peru 
Table 1 (continued on next page). Comparison of Amazonian species. Refers to both sexes except where noted.

\begin{tabular}{|c|c|c|c|}
\hline & C. major sp. nov. & C. nahvalr sp. nov. & C. adisi sp. nov. \\
\hline \multicolumn{4}{|l|}{ Character } \\
\hline Locality & Primary upland forest & Secondary upland forest & Mixed water \\
\hline Size (males) & Large $(18-39 \mathrm{~mm})$ & Medium (11-29 mm) & Small $(10-22.5 \mathrm{~mm})$ \\
\hline Tergite no. (males) & $66-87$ & $43-85$ & $53-78$ \\
\hline Rostrum shape & $\begin{array}{l}\text { Abruptly defined from head } \\
\text { in dorsal view, less so } \\
\text { laterally; horizontal }\end{array}$ & $\begin{array}{l}\text { Abruptly defined from head both in } \\
\text { dorsal and lateral view; } \\
\text { slightly curved ventrally }\end{array}$ & $\begin{array}{l}\text { Abruptly defined from head both in } \\
\text { dorsal and lateral view }\end{array}$ \\
\hline Length of antennae & $\begin{array}{l}\text { Surpassing rostrum by very } \\
\text { large amount }(162 \%)\end{array}$ & $\begin{array}{l}\text { Surpassing rostrum by large amount } \\
(115 \%)\end{array}$ & $\begin{array}{l}\text { Surpassing rostrum by large amount } \\
(120 \%)\end{array}$ \\
\hline Rostrum to base of antennae & $0.6-0.8 \mathrm{~mm}$ & $0.5-0.8 \mathrm{~mm}$ & $0.26-0.5 \mathrm{~mm}$ \\
\hline $\begin{array}{l}\text { Head width (between antennal } \\
\text { sockets) }\end{array}$ & $\begin{array}{l}0.7-0.8 \mathrm{~mm} \\
( \pm \text { same as rostrum length) }\end{array}$ & $\begin{array}{l}0.3-0.6 \mathrm{~mm} \\
\text { (less than rostrum length) }\end{array}$ & $\begin{array}{l}0.2-0.34 \mathrm{~mm} \\
\text { (less than rostrum length) }\end{array}$ \\
\hline Paranota/tergal ridges & $\begin{array}{l}\text { Metatergal ridges but not } \\
\text { strong; no paranota }\end{array}$ & Strong metatergal ridges; no paranota & Metatergal ridges; no paranota \\
\hline Dorsal view of body rings & $\begin{array}{l}\text { Prozonite and metazonite } \\
\text { about the same width }\end{array}$ & $\begin{array}{l}\text { Prozonite wider than metazonite } \\
\text { Rings relatively short and wide }\end{array}$ & $\begin{array}{l}\text { Prozonite about same width as } \\
\text { metazonite or narrower } \\
\text { Rings relatively narrow }\end{array}$ \\
\hline Collum & $\begin{array}{l}\text { Shallow curve but thickened } \\
\text { area with strong anterior V }\end{array}$ & V shape well pronounced & Shallow curve, although well pronounced \\
\hline Head & Strongly tuberculate & Strongly tuberculate & Strongly tuberculate \\
\hline Antenomere 2 & As wide as long & Longer than wide & As wide as long \\
\hline Sternite & Strong tubercles all over & Some tubercles & Some tubercles \\
\hline $\begin{array}{l}\text { Limit of prozonite and meta- } \\
\text { zonite }\end{array}$ & Line of setae & Line of setae & Line of setae \\
\hline Ozopore & On little prominence & Perhaps on little prominence? & On little prominence \\
\hline $\begin{array}{l}\text { Setae length relative to body } \\
\text { size }\end{array}$ & $0.06-0.14$ & $0.04-0.1$ & Short $0.03-0.07$ \\
\hline
\end{tabular}


Table 1 (continued).

\begin{tabular}{|c|c|c|c|}
\hline & C. major sp. nov. & C. nahvalr sp. nov. & C. adisi sp. nov. \\
\hline \multicolumn{4}{|l|}{ Character } \\
\hline Pleurite ventral margin & With sharp notch & Bilobed & Shallow notch \\
\hline Limbus of pleurite & $\begin{array}{l}\text { Crenulate bumps but have to } \\
\text { look from underneath }\end{array}$ & $\begin{array}{l}\text { Lateral edges serrate although not as } \\
\text { strong as C. adisi sp. nov. no setae }\end{array}$ & Strongly serrate \\
\hline Limbus of tergite & Crenulate & Crenulate & Crenulate \\
\hline Tubercules & $\begin{array}{l}\text { Large and numerous, some } \\
\text { intact }\end{array}$ & Abundant & Abundant \\
\hline Spiracles & Normal & $\begin{array}{l}\text { Clearly visible and with appearance of } \\
\text { 'silk cloth' inside }\end{array}$ & As $C$. nahvalr sp. nov. \\
\hline Coxae & Strong tubercles all over & Rugose but no tubercles & Some tubercles \\
\hline Claw & $\begin{array}{l}\text { Groove underneath and a } \\
\text { slight expansion }\end{array}$ & Groove ventrally & Slight membrane ventrally \\
\hline Accessory claw & $\begin{array}{l}\text { Short }(<1 / 2 \text { claw length) but } \\
\text { thick, on anterior ventral } \\
\text { side of claw }\end{array}$ & $\begin{array}{l}\text { Very strong and appearing to reach } \\
\text { within } 25 \% \text { of the tip of the claw. } \\
\text { Slightly anterior dorsally }\end{array}$ & $\begin{array}{l}\text { Very strong and appearing to reach } \\
\text { within } 25 \% \text { of the tip of the claw. } \\
\text { Anterior ventral to claw }\end{array}$ \\
\hline Anterior gonopods (males) & Bent anteriorly; spinose. & Strongly bent anteriorly; spinose & $\begin{array}{l}\text { Strongly bent anteriorly with clear knee } \\
\text { before last two apical segments, slight } \\
\text { knob at base of 'knee' }\end{array}$ \\
\hline Posterior gonopods (males) & Simple hyaline tip & Simple hyaline tip & Simple hyaline tip \\
\hline
\end{tabular}




\section{Key to species of Columbianum from Amazonia}

Note that it would be preferable for the key to include all species of Columbianum, but as some of the published descriptions are poor this would require more comprehensive work which is outside the scope of this study.

1 Large, dark and robust species, body width at least $1.8 \mathrm{~mm}$

C. major sp. nov.

- Smaller species, body width less than $1.0 \mathrm{~mm}$ 2

2 With strongly domed head and very narrow rostrum; head and metazonites with tubercles but not appearing rugose; prozonites wider than metazonites; medium sized (body width $0.8-1.2 \mathrm{~mm}$ ) ......

C. nahvalr sp. nov.

- With clear distinction between head and rostrum, but head not strongly domed; very rugose, with abundant tubercles on head and metazonite; prozonites the same width as metazonites or narrower; smaller size (body with $0.59-0.98 \mathrm{~mm}$ )

C. adisi sp. nov.

See also Table 1 for comparisons between the three species.

Columbianum major sp. nov.

urn:1sid:zoobank.org:act:B70F0790-B0B1-4540-B9E3-61879FF1CEB7

Figs $1-3$

\section{Diagnosis}

Large, dark, robust species. Rostrum abruptly set off from head when seen in dorsal view but head not domed. With narrow ridge-like metazonites anteriorly. Metatergites with a dense and even cover of setae and tubercles all over. Limbus crenulated, and probably the hind edge of the pleurites, too. Simple claws and accessory claws. Posterior and anterior gonopods composed of several clear segments but no large projections or forks on either.

\section{Etymology}

Comparative adjective relating to the relatively large overall size of this species.

Material studied $(2 \hat{\jmath}, 3$ + $\rho)$

\section{Holotype}

BRAZIL: ${ }^{\prime}$, Amazonas Province, Reserva Flor. A. Duche, Terra Firma, 255’ S, 5959’ W, 14 Feb. 1996, primary upland forest, not inundated, Adis et al. leg. (INPA).

\section{Paratypes}

BRAZIL: 1 ○, same data as for the holotype, 17 Apr. 1996, ZFII 3, soil emergence trap (ZMUM); 2 우, same data as for the preceding, 20 Feb. 1992, standing crop samples (ZMUM, INPA); 1 (smaller paler specimen), same data as for the preceding, 8 Dec. 1982, K12 RD4, Kempson extractor (INPA).

\section{Description}

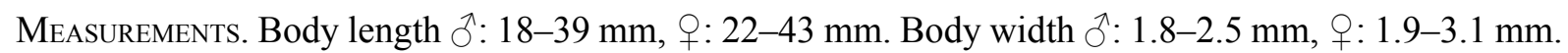
Number of podous tergites: ${ }^{7}: 66-87$,, : 78-94. Number of apodous tergites: 1.

CoLour. Deep brown (except smallest specimen which is pale); generally darker at anterior end, to rings 15-20. Head and legs variable but paler, antennae dark or pale.

Body SHAPE (Fig. 2A). More or less parallel sided, attenuated posteriorly. 
HeAd (Fig. 2B-C). Pilose, width (between antennal sockets) $0.7-0.8 \mathrm{~mm}$. Sharp transition from head to rostrum when seen from above, more gradual from the side, head not domed. Length of rostrum from tip to antennal base: $0.6-0.8 \mathrm{~mm}$. Rostrum appearing relatively short in relation to body size (but relative length difficult to evaluate as head is tucked under collum so very little is showing from dorsal view). Rostrum more or less horizontal in lateral view, with short setae along the entire length and a few longer ones at the base, these setae reaching almost to tip of rostrum.

ANTENNAE. Slightly shorter than body width (1:0.85), much longer than rostrum and surpassing it by over $150 \%$ of rostrum length. Length:width ratio of antennomeres 1-8: 1-broken, 1.73, 1.03, 0.95, $0.83,1.8,7$-heavily sclerotised and difficult to see, sensory cones not measured. Sensory pits present on antennomeres 5 and 6 , with numerous sensory organs in each.

Collum. Densely pilose; anterior margin appearing very deeply V-shaped under light microscope but with a thin membrane across the apparent incision, anterior margin actually only smoothly curved posteriorly. Tergite 2 half the length of the collum or less.

MidBody RINGS. When plotted this species forms a group with a larger body width for a similar number of segments, relative to the other species (Fig. 1). No obvious paranota but a slight angle to the body shape in cross section in mid to posterior part of trunk with the angle where the repugnatorial glands occur. Metazonites standing slightly proud of prozonites and appearing as a ridge on anterior segments, smoother outline posteriorly. Relative width of pro- and metazonites approximately 0.89 . Anterior margin of tergites smooth at midpoint, with dense and even cover of setae, tuberculate all over. Channel between pro- and metazonites with clear line of setae. Length of longest metazonital setae $0.06-0.14 \times$ body width. Limbus crenulate (Fig. 2D). Pleurites densely pilose, hind edge possibly serrate, ventral margin with sharp notch for the coxae and curved posterior edge (Fig. 2E-F). Ozopores present from tergite 6 to penultimate tergite, very round in shape, situated in the middle of the ridge formed by the metazonite anteriorly, moving to the posterior edge of the ridge more posteriorly.

LEGS. Length 0.54 of the body width. Length: width ratio of podomeres (prefemur to claw): 1.19, 1.57, $1.35,1.73,3.12,2.83$. Coxae covered in tubercles and with obvious pores. Tarsus very long and narrow. Claw with ventral groove, slightly thickened. Accessory claw approximately $50 \%$ of the claw length, strong and arising from base of anterior side; visible using light microscope in anterior legs of females (difficult to see in males due to poor preservation) (Fig. 3A). Overall appearance of claw + accessory claw almost like a double claw.

Telson. Length width ratio: 1.7-2.9.

MALE ANTERIOR LEGS (pairs 1-8). Without modifications.

ANTERIOR GONOPODS (Fig. 3). Apparently with six 'segments' (including coxa) but poorly preserved. Distally coming to a gradual point with a hyaline projection at tip but hidden in abundant setae. Third segment with small posterior lobe on the mesal side. Several prominent setae on inside and outside of the 'knee'.

Posterior GONOPODs (Fig. 3). Apparently with five 'segments' (including coxa). Distal segment long and thin, coming to simple point. A small 'nick' near base of terminal part. As specimens are poorly preserved other projections or spines may have been broken.

\section{Comments on ecology}

Columbianum major sp. nov. was found only in the primary upland forest. 

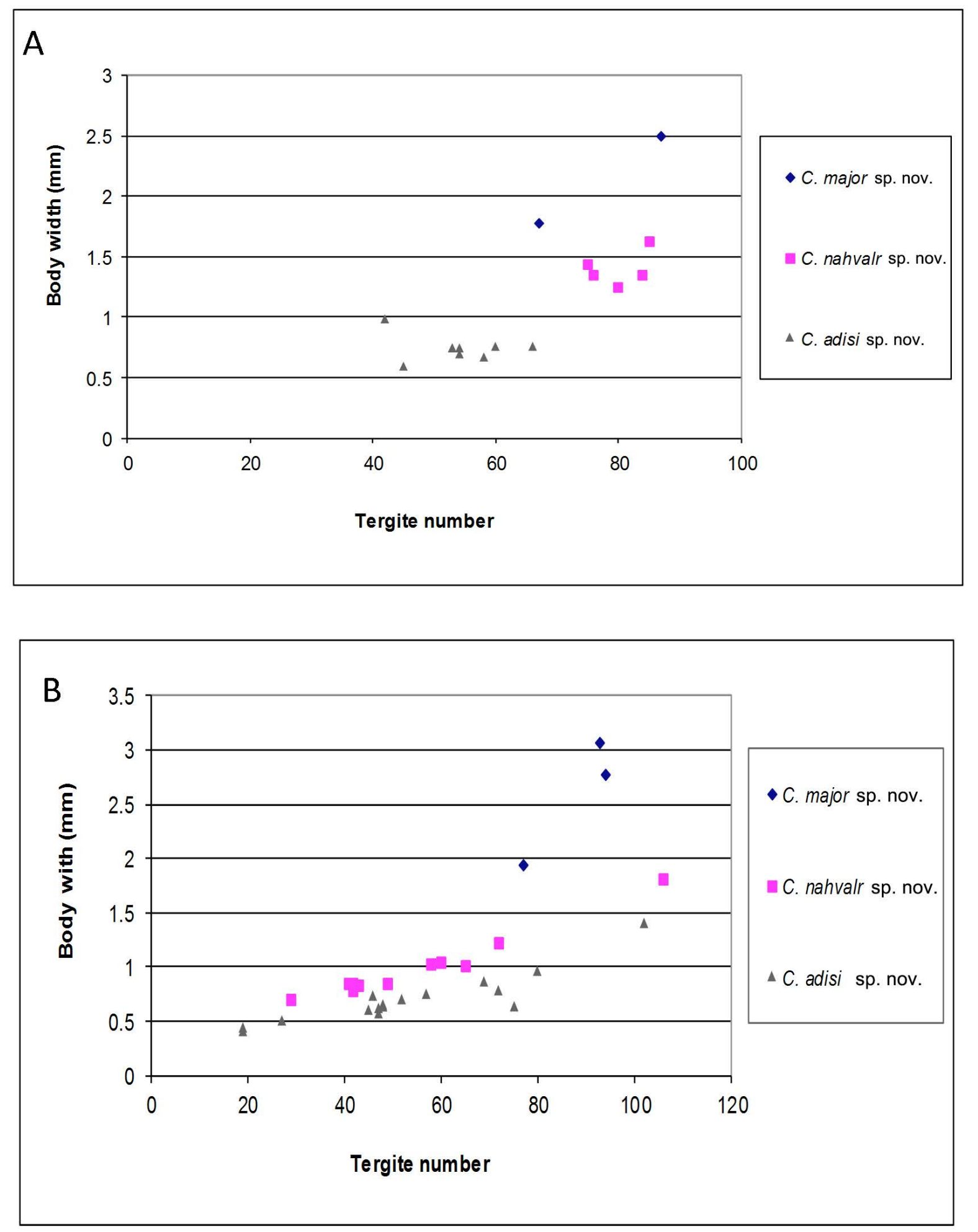

Fig. 1. Body width (mm) against the total number of tergites with legs for new species of Columbianum Verhoeff, 1941. A. Males. B. Females. 


\section{Additional comments}

These specimens appear to have been hand-collected (in contrast to other specimens) so the colour is perhaps more similar to live colour, however the state of preservation of most of them is poor, and many of the appendages are damaged or broken and so difficult to measure accurately. Due to the relatively few specimens scanning electron mounts were only made of midbody segments.
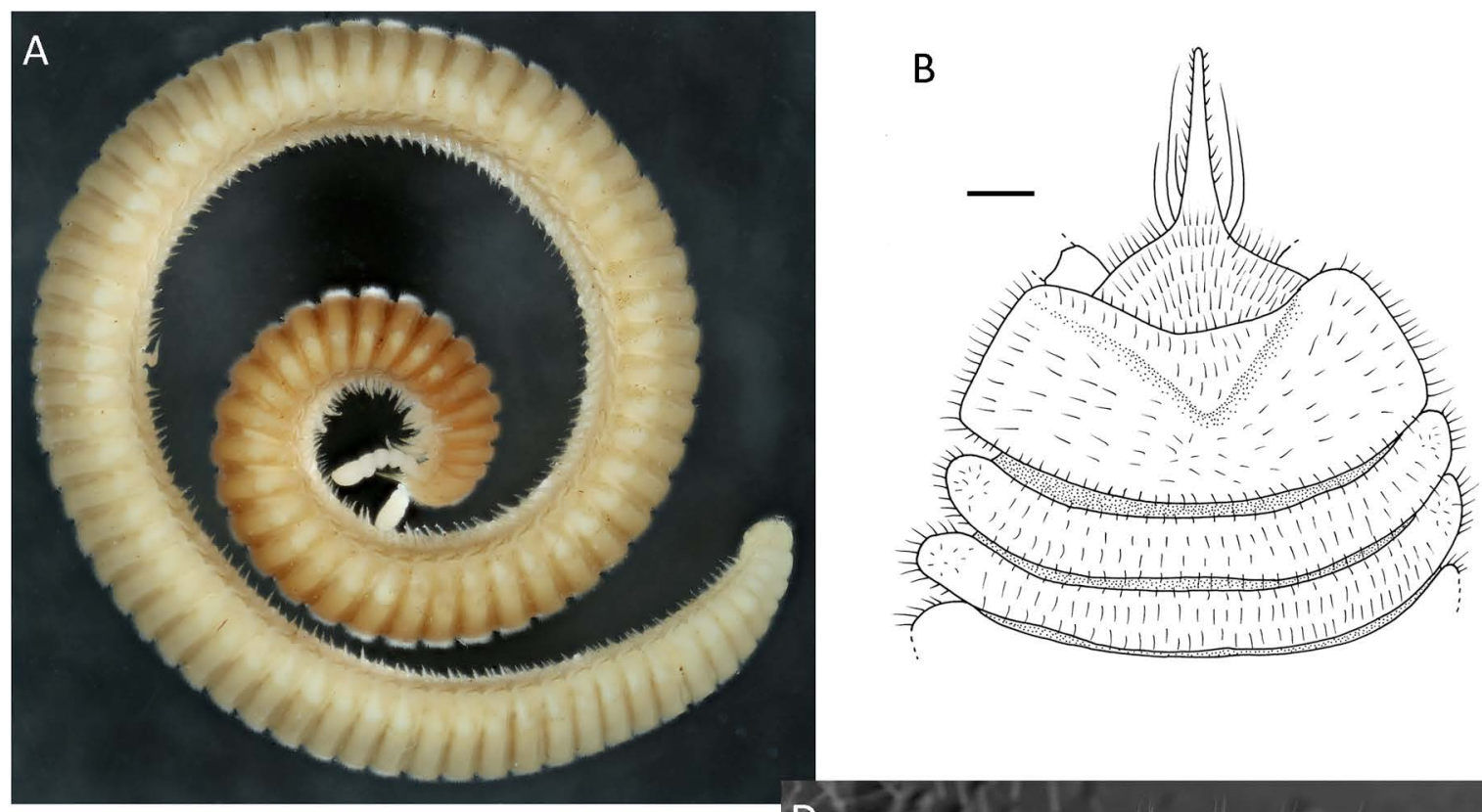

C
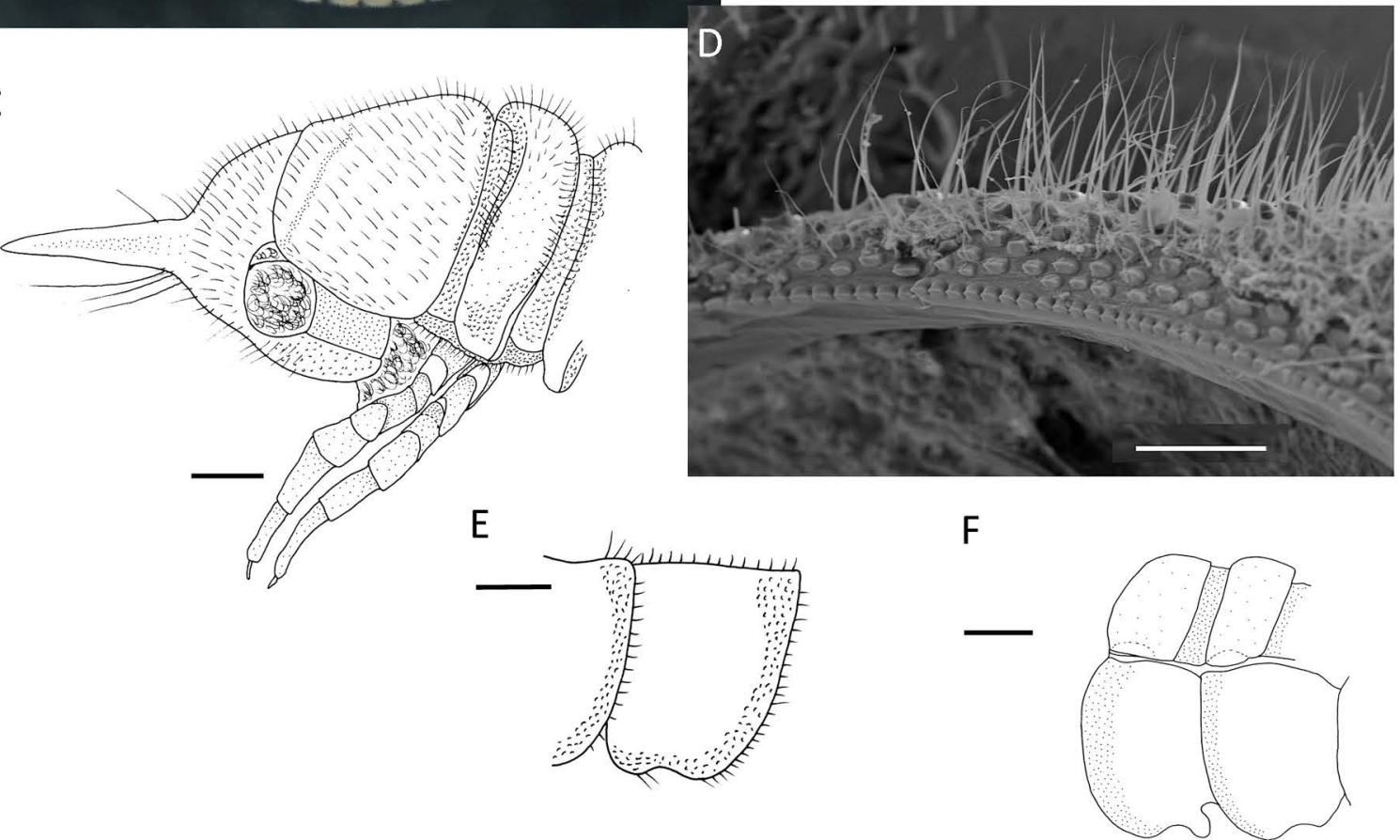

Fig. 2. Columbianum major sp. nov. A. Habitus of largest female paratype from Reserva Duche Terra Firme. Total length $43 \mathrm{~mm}$. B-C, E-F. Holotype, $\hat{\sigma}^{\widehat{*}}$. B. Head and anterior tergites in dorsal view. C. Head and anterior rings in lateral view. D. Paratype, $\widehat{\partial}$. Limbus of midbody metazonite of male in posterior view. E. Pleurites in lateral view, midbody rings (anterior to left). F. Pleurites in lateral view, rings 6 and 7 (anterior to left). Scale bars $=B-C, E-F=0.2 \mathrm{~mm}$; D $=0.1 \mathrm{~mm}$. 


\section{Columbianum cf. major}

\section{Material studied}

BRAZIL: 1 đ Pará, Santarém, Taperinha, 16 Nov. 1970, S.L Tuxen and O. Jensen leg. (NHMD); 1 đ, 1 ㅇ, Pará, Santarém, Taperinha, 9 Nov. 1970, O. Jensen leg. (NHMD).

COLOMBIA: 1 juv., Sierra Nevada de Sta Marta, near Duriameina, ca 3600 m, 7 Dec. 1978, under stones, H. Sturm leg. (NHMD); 1 juv., E. Cordillera, Monterreanda mountain forest, ca 2000 m, 31 Dec. 1955, litter, H. Sturm leg. (NHMD).

These specimens are clearly Columbianum. Those from Brazil are very similar to C. major sp. nov., although rather smaller in size and with fewer tergites. One mature male has well-developed gonopods but only $55+1$ tergites. The female in the same sample has $72+1$ tergites. Those from Colombia are also similar in head shape and overall morphology to C. major sp. nov. but tiny in comparison, one with just $26+1$ tergites, and appear to be from rather a different habitat.

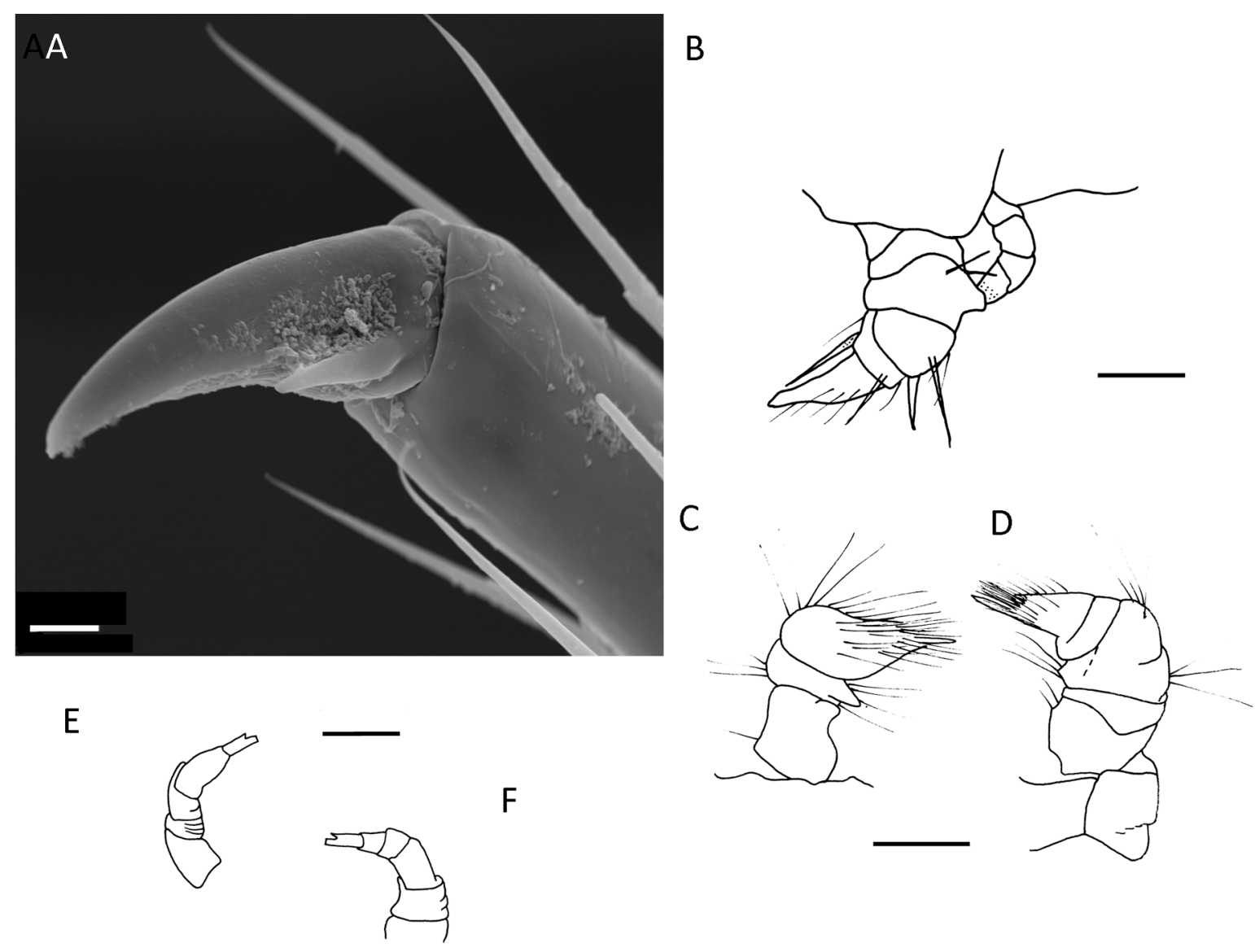

Fig. 3. Columbianum major sp. nov. A. Tarsal claw and accessory claw of midbody leg from right side of male, anterior view. B-F. Gonopods of holotype male. B. In situ (apex of posterior gonopod hidden behind the anterior gonopods). C. Anterior gonopod in lateral view. D. Anterior gonopod in mesal view. E. Posterior view in lateral view (apex broken). F. Posterior gonopods in mesal view (apex broken). Scale bars $=\mathrm{A}=0.01 \mathrm{~mm} ; \mathrm{B}-\mathrm{F}=0.2 \mathrm{~mm}$. 


\section{Columbianum nahvalr sp. nov. \\ urn:1sid:zoobank.org:act:FA3360D7-B4BD-4DB8-B248-97C92EF1517B}

Figs $1,4-5$

\section{Diagnosis}

Fairly large pale species. Rounded and domed head with sharp distinction between head and narwhallike rostrum. Tubercles and setae on metazonites abundant and irregular, setae quite long, giving a rather ragged appearance. Prozonites without tubercles. Channel between pro- and metazonite with horseshoeshaped tubercles. Limbus crenulated like posterior margin of pleurites. Accessory claws robust, roughly half the length of claw and situated on the dorso-anterior side of claw. Anterior gonopods resembling walking legs with a simple distal claw.

\section{Etymology}

Noun in apposition referring to the Old Norse name for the narwhal (Monodon monoceros Linnaeus, 1758). The head of our species strongly resembles the head of the narwhal.

Material studied $(6 \hat{\partial} \widehat{\partial}, 1$ juv. $\curvearrowright, 9$ 우)

\section{Holotype}

BRAZIL: ${ }^{\top}$, Amazonas Province, Rio Taruma Mirim, $3^{\circ} 02^{\prime} \mathrm{S}, 60^{\circ} 17^{\prime} \mathrm{W}$, Capoeira, secondary upland forest, Terra Firma, not inundated, 0-7 cm, K29 TU, 25 Apr. 1983, Adis and Rodrigues leg. (INPA).

\section{Paratypes}

BRAZIL: $1 \hat{\jmath}, 2$ 우, 1 juv. $\hat{\jmath}$, same data as for the holotype (1 $\hat{\sigma}$ NHMD, the rest INPA).

Other specimens $(4 \hat{\partial} \hat{\partial}, 7 \stackrel{+}{q})$

All from the same locality with dates between Apr. 1982 and Apr. 1983. Specimens split between INPA, NHMUK, NHMD and ZMUM.

\section{Description}

MEasurements. Body length $\delta^{\lambda}: 11-29 \mathrm{~mm}, q: 9-18$. Body width $\delta^{\text {T. }}: 0.8-1.6 \mathrm{~mm}, q: 0.8-1.2$. Number of podous tergites ${ }^{\top}: 43-85, q: 41-106$. Number of apodous tergites: $0-2$.

CoLour. Various shades of yellow/white. Perhaps with darker spots near repugnatorial glands.

BODY SHAPE. More or less parallel-sided in central trunk region. Attenuated anteriorly and posteriorly.

HEAD (Fig. 4C-D). Densely pilose all over and covered in regular, sub-circular tubercles, including the antennae. Width (between antennal sockets) $0.3-0.6 \mathrm{~mm}$. Head very sharply defined from rostrum in dorsal view, slightly rounded anteriorly. In lateral view head so domed that an abrupt 'step' is formed between head and rostrum. Length of rostrum to antennal base: $0.5-0.8 \mathrm{~mm}$. Rostrum slightly downcurved, with several long setae at base, almost reaching tip of rostrum and smaller lateral ones on both sides of the whole length.

ANTENNAE. About the same as the body width (1:1.06), long in relation to rostrum, clearly surpassing it by over $100 \%$ of the rostrum length. Length:width ratio of antennomeres $1-8: 0.82,1.3,1.12,0.95$, $0.96,1.6,0.45$, sensory cones at apex not measured. Sensory pits on antennomeres 5 and 6 , with a large number of sensilla.

Collum. Covered with tubercles and setae; anterior margin appearing sharply V-shaped in some specimens but in reality a thinner region anteriorly with a shallow posterior curve (also seen under SEM). Tergite 2 much less than half the length of collum. 
MidBody SEGMENTS. When the number of tergites are plotted relative to body length this species forms an intermediate group on the graphs (Fig. 1). No obvious paranota-type structure, although there may be slight bumps where the repugnatorial glands exit, appearing more pronounced by a ring of "palisadelike' setae. In dorsal view it appears as if there are small paranota but these consist of the metazonital ridges. Clear differences in height of pro- and metazonite so that the metazonite stands proud, and the whole appearance when viewing the animal from the side is of a castellated dorsal margin (Fig. 5A). Relative width of pro- and metazonite: $0.78-0.88$. Prozonites with cytoscutes but without any tubercles and lacking setae. Metazonites with numerous tubercles and setae. Under SEM tubercles very uneven in shape. Setae rather long and uneven, giving the animal a slightly ragged look. Setae apparently of similar length regardless of the size of the individual so appearing longer in smaller specimens. 'Channel' between pro- and metazonite with tubercles appearing horseshoe-shaped; possibly due to the partial collapse of more blister-like structures (Fig. 5B). Setae 0.04-0.1 $\times$ body width. Limbus crenulated. Pleurites setose and with curved posterior margin, ventral margin bilobed, hind margin crenulated. Ozopores present from tergite 5 to the ultimate tergite, on tergal ridges, in anterior $1 / 4$ located more or less centrally on ridge, in posterior $3 / 4$ on posterior margin of ridge. Some appearing on very slight protuberance probably largely due to the slight change in angle of the tergite at this point.

LEGS. Length $0.57 \times$ body width. Length:width ratio of podomeres (prefemur to claw): $1.54,1.69,1.1$, $1.47,3.31,4.25$. Tarsus very long and narrow. Claw rather angular in shape and with slightly thickened
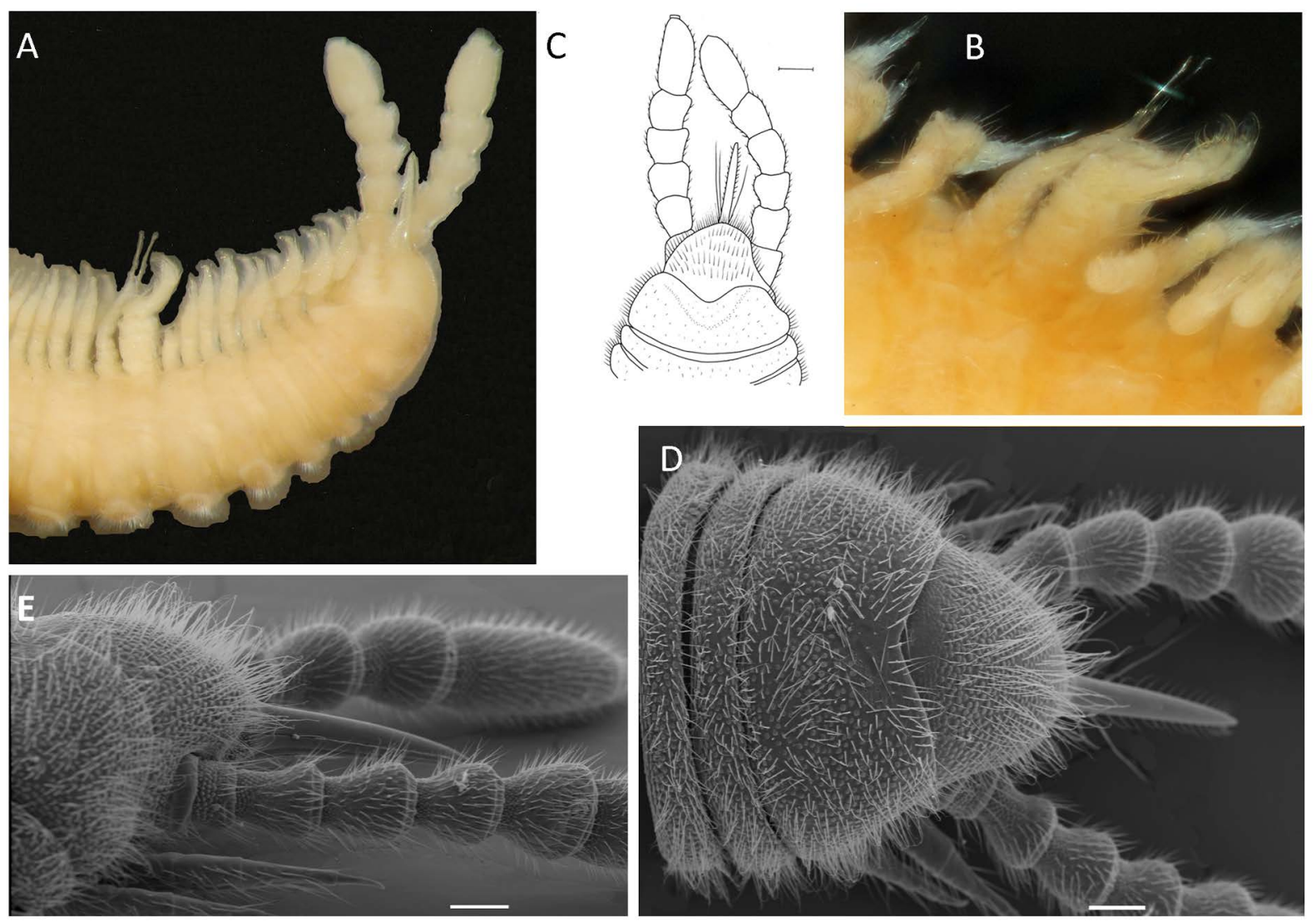

Fig. 4. Columbianum nahvalr sp. nov. A. Head and anterior body rings of male, showing the appearance of gonopods in a 'relaxed specimen'. Body width approximately $1 \mathrm{~mm}$. B. Close up of gonopods in a 'relaxed' specimen. Body width approximately $1 \mathrm{~mm}$. C. Head of holotype male in dorsal view. Note long setae originating from base of rostrum. D. Head and rostrum of female in dorsal view. E. Head and rostrum of female in lateral view. Scale bars $=\mathrm{C}=0.2 \mathrm{~mm}$; $\mathrm{D}-\mathrm{E}=0.1 \mathrm{~mm}$. 
region at base on anterior side. Accessory claw slightly shorter than claw but substantial in size and thickness, arising from anterior-dorsal side of the claw (Fig. 5C). Accessory claw can be seen under light microscope and makes it appear as if there is a double claw at the end of the tarsus when seen in dorsal view, less obvious in anterior view because the accessory claw does not project beyond the claw. In females these 'double claws' only seem to be obvious at the anterior end of the body, in males they are apparent almost the whole length. Coxal pores present and large at least on some specimens.

Telson. Rounded, length:width ratio: 1-2.4.

MALE FIRST PAIRS OF LEGS (1-8). Appear normal.

ANTERIOR GONOPODS (Figs 4B, 5D-E). With five segments (including coxa). Distally a simple claw, the whole structure very reminiscent of a normal walking leg but rather stouter and with especially stout

A
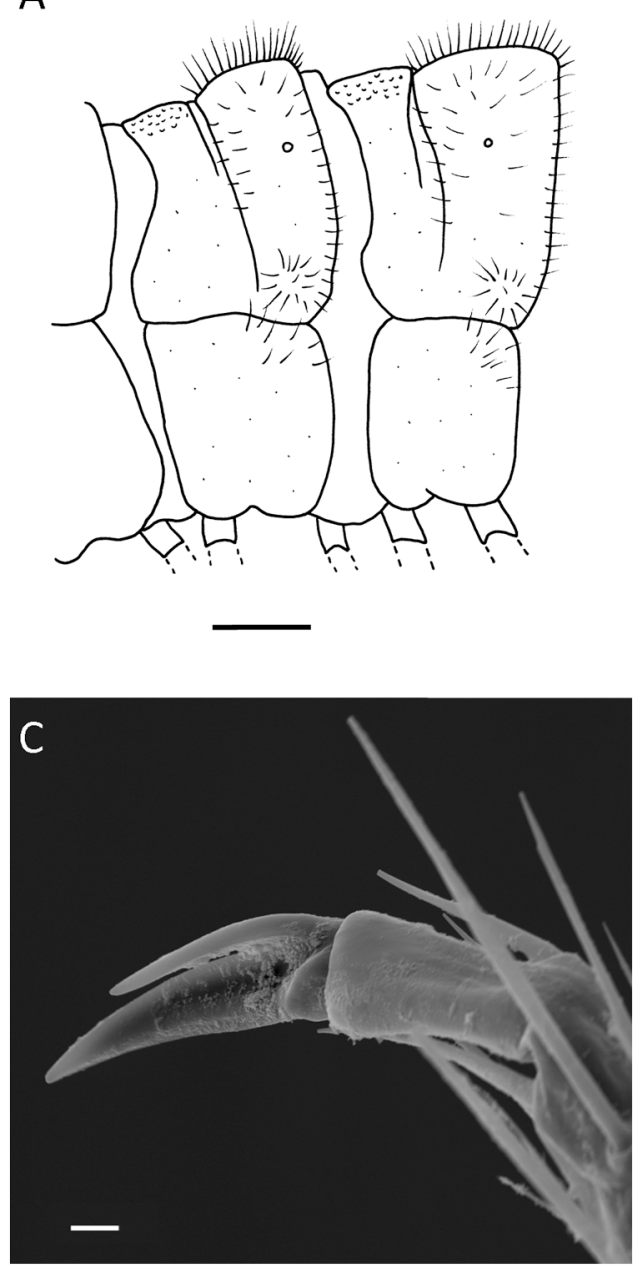

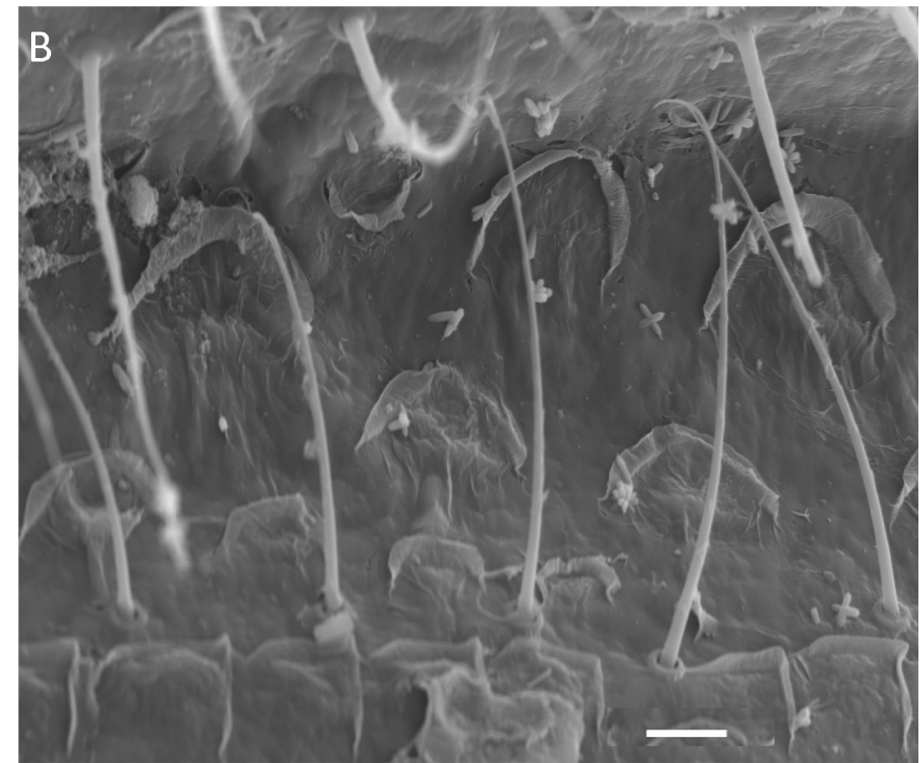

$\mathrm{E}$

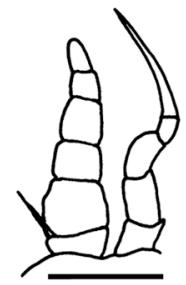

Fig. 5. Columbianum nahvalr sp. nov. A. Midbody rings from lateral view, showing pronounced difference between pro- and metazonite and shape of pleurites. B. 'Channel' between pro- and metazonite in dorsal view of male showing tubercles and line of setae. C. Tarsal claw and accessory claw of midbody leg from right side of male, in anterior dorsal view. D. Gonopods of holotype male, lateral view with anterior gonopods to right. E. Gonopods of small, presumably immature male, in lateral view, anterior gonopds to left. Scale bars $=A, D-E=0.2 \mathrm{~mm} ; \mathrm{B}-\mathrm{C}=0.01 \mathrm{~mm}$. 
and bent tibia. Abundant setae on terminal two podomeres, including a tuft of short setae just below the base of the last segment, on the posterior side and more setae on the top of the 'knee'. Several prominent setae on anterior margin of basal three segments.

POSTERIOR GONOPODS (Figs 4B, 5D-E). Number of segments may be 5-7 (including coxa) but distinction between segments unclear. Distal part a simple hyaline tip with slight notch and two small 'nicks' towards the tip at least on some specimens.

\section{Note}

The gonopods of this species appear from the drawings (Fig. 5D) to be clearly distinct from those of C. major sp. nov. (Fig. 3). In reality this is because all specimens of $C$. nahvalr sp. nov. are very relaxed and the gonopods much easier to see; those of $C$. major sp. nov. are tightly compressed and also poorly preserved.

\section{Comments on ecology}

All specimens of C. nahvalr sp. nov. were obtained from Kempson extractors suggesting that this species is soil dwelling.

\section{Columbianum adisi sp. nov. urn:1sid:zoobank.org:act:F5FF2BE1-3EDB-4288-BF21-4CB25E8D9EF5}

Figs 1,6

\section{Diagnosis}

Small thin species with a clear demarcation between head and rostrum both in lateral and dorsal views. Very rugose with more or less regular and sub-circular tubercles all over the head, metazonites and the channel between the pro- and metazonite, some of these being 'anchor'-shaped from the side. Limbus with crenulations. Posterior edge to pleurites with saw-shaped teeth, only visible from certain orientations and perhaps due to the tubercles. Accessory claw robust and visible under light microscope. Anterior gonopods with ribbon-like setae on distal segment, posterior gonopods with a simple hyaline tip.

\section{Etymology}

Named in honour of the late Joachim Adis (1950-2007) who carried out extensive work in Brazilian Amazonia and collected many of the specimens studied here

Material studied $(11 \hat{\delta} \hat{\sigma}, 18 q+$ )

\section{Holotype}

BRAZIL: ${ }^{\top}$, Amazonas Province, Lago Janmauri, 03²0’ S, 60¹7' W, 14 Sep. 1987, agua mista, Kempson extractor K10-19, Adis et al. leg. (INPA).

\section{Paratype}

BRAZIL: 1 , same data as for the holotype (INPA).

\section{Other specimens $(10 \hat{\partial} \widehat{\partial}, 17 \stackrel{+}{\phi})$}

Locality as above, BE $\downarrow 50$ A: 1 Jan. 1987, 1 Jul. 1987, 14 Jul. 1987, 31 Jul. 1987; BE $\downarrow 50$ B: 15 Jun. 1988, 1 Jul. 1987; BE $\downarrow 50 C: 17$ Apr. 1987, 1 Jul. 1987, 31 Jul. 1987; BE $\downarrow 50 D: 1$ Jul. 1987, 14 Jul. 1987, 31 Jul. 1987; BE 449: 16 May 1988; Kempson extractors (K23-11: 14 Mar. 1988; K19-11: 14 Feb. 1988; K2011: 14 Feb. 1988; K29-11: 13 Oct. 1987; K20-11: 12 May 1988; K26-11: 13 Oct. 1987; K11-29: 14 Nov. 1987 (split between INPA, ZMUM, NHMD and NHMUK). 


\section{Description}

MEAsurements. Body length $\delta^{\lambda}: 10-22.5 \mathrm{~mm}$,, : up to $15.5 \mathrm{~mm}$. Body width $\delta^{\lambda}: 0.59-0.98 \mathrm{~mm}$, + : 0.41$1.4 \mathrm{~mm}$. Number of podous tergites $\delta^{\jmath}: 53-78$, , + : 19-102. Number of apodous tergites: $0-1$.

CoLour. An even pale yellow all over, some individuals brownish.
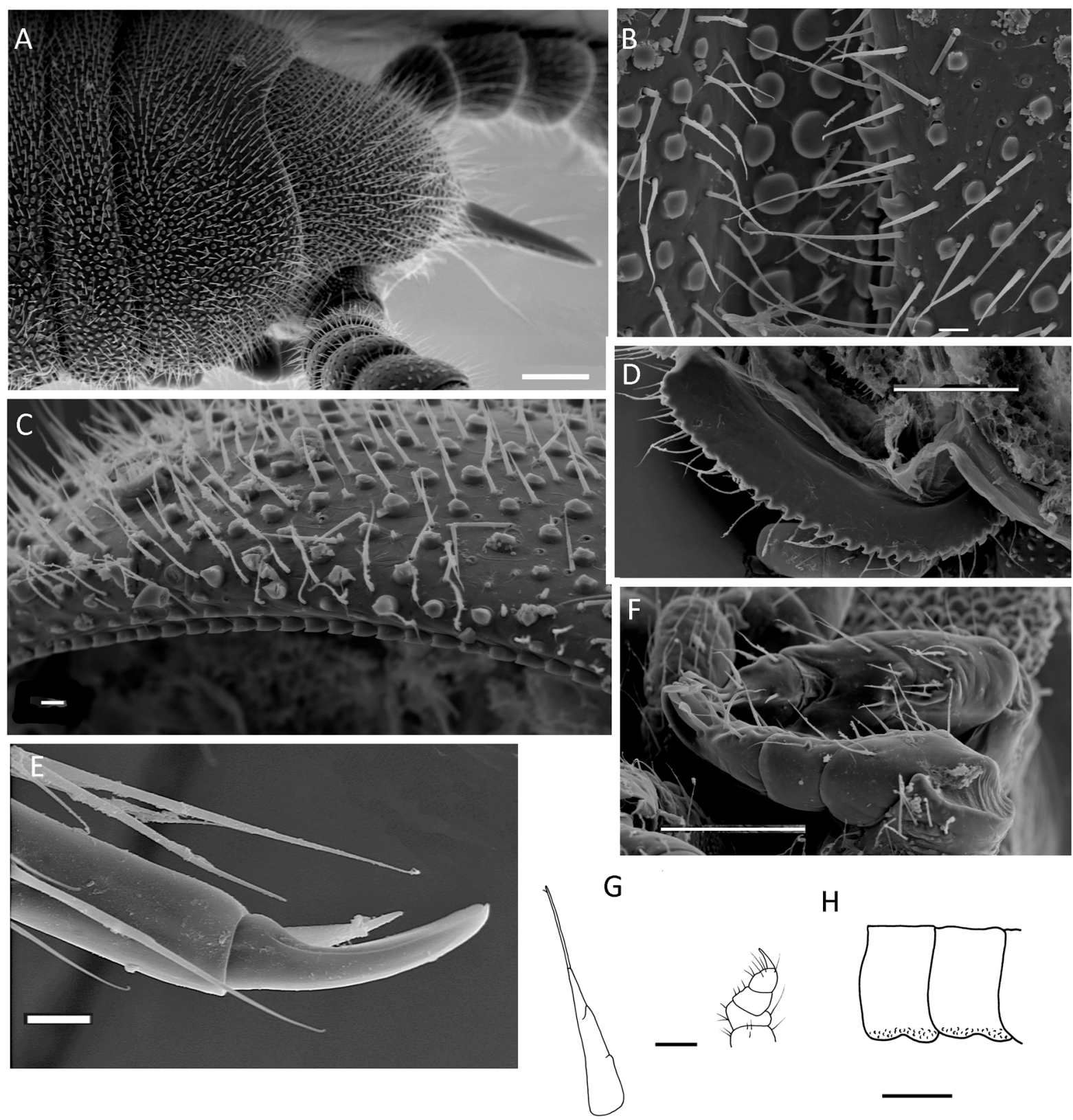

$\mathrm{H}$

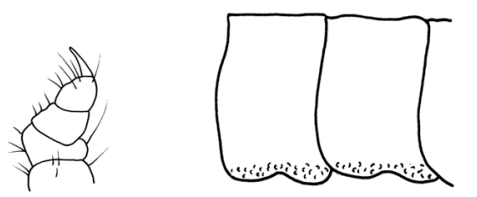

Fig. 6. Columbianum adisi sp. nov. A. Head and first few rings of male in dorsal view. B. Dorsal view of midbody ring from male showing detail of tubercles. C. Dorsal view of midbody ring from male showing detail of limbus. D. Midbody ring from male showing hind edge of pleurite from the inside. E. Midbody claw and accessory claw from male in posterior ventral view. F. Male anterior gonopods in situ. G. Male gonopods in lateral view, posterior (left) and anterior (right). H. Lateral view of pleurites from front end of female paratype. Anterior to left. Scale bars $=A, D$, $\mathrm{F}=0.1 \mathrm{~mm} ; \mathrm{B}-\mathrm{C}, \mathrm{E}=0.01 \mathrm{~mm} ; \mathrm{G}-\mathrm{H}=0.2 \mathrm{~mm}$. 
BODY SHAPE. More or less parallel-sided, perhaps slightly narrower anteriorly.

HEAD (Fig. 6A). Covered in regular, sub-cylindrical setae, width (between antennal sockets) $0.2-$ $0.34 \mathrm{~mm}$. With abrupt anterior margin between head and rostrum in dorsal view, head domed in lateral view making clear division between head and rostrum. Length of rostrum from tip to antennal base $0.26-0.5 \mathrm{~mm}$.

ANTENNAE. Longer than the body width (1.12:1), appear long in comparison to rostrum, surpassing it by at least one antennal segment and usually substantially more, and over $120 \%$ of rostrum length in analysed specimens. Length:width ratio of antennomeres: $0.8,0.97,1,1.03,0.95,1.87,0.5$, sensory cones not measured. Sensory pits on antennomeres 5 and 6 clearly present.

Collum. Anterior margin appearing strongly V-shaped in light microscope but much more gradually curved under SEM, the difference may be due to the relative invisibility of an area without tubercles under light microscope. Tergite 2 length much shorter than collum.

MidBody SEGMENTs. When plotted this species forms a group with a small body size and a low number of tergites (Fig. 1). Paranota absent. A clear and definite 'dip' between pro- and metazonite present. Relative length of pro- and metazonite $0.87-0.92$. Surface structure of pro- and metazonites generally very tuberculate. Tubercles appearing more or less regular on the metazonites and in at least one specimen some of the tubercles are like collapsed blisters as seen in C. nahvalr sp. nov. On the anterior margin are tubercles appearing 'anchor-like' which may be partly related to the lateral view (Fig. 6B). Metazonites with lots of setae. Prozonites with rugose appearance due to cytoscutes but with a smoother region mid-dorsally. 'Channel' region between pro- and metazonite with subcircular, clearly pronounced tubercles. Setae short, $0.03-0.07 \times$ body width. Limbus with clear and regular row of semi-circular bumps (under SEM, Fig. 6C). Pleurites ventrally with notch at least in anterior part of body (Fig. 6H); posterior margin saw-like under SEM, only seen from certain angles, maybe due to the tubercles in cross section (Fig. 6D). Ozopores present from tergite 5 to the last tergite, on slight protuberance as seen under SEM, this perhaps seems more obvious due to the 'palisade' of setae round the rim.

LeGs. Length $0.62 \times$ height. Length:width ratio of podomeres (prefemur to claw): 1.37, 1.5, 0.87, 1.21, $1.21,3$. Tarsus slightly longer than wide. Claw normal. Accessory claw on anterio-ventral side of claw, short and reaching to less than half the length of the claw (22\% of claw length on slides) but very robust and visible under light microscope (Fig. 6E). Coxal pores present.

TELSON. Rounded and of normal shape, length width ratio: 0.33 .

MALE FIRST PAIRS OF LEGS. First pair thickened, with claw and accessory claw like normal walking legs.

ANTERIOR GONOPODS. With five segments (including coxa). Distally simple, the most distal 'segment' with flattened ribbon-like setae as seen in SEM and without any apparent groove or other structure medially in ventral side to hold in the posterior gonopods although they are pressed very tightly together. Accessory lobe on 'segment' below the knee. Setae abundant on whole structure.

POSTERIOR GONOPODS. With an indeterminate number of segments. Distally a simple hyaline tip, with one or more small nicks close to the tip.

\section{Remarks}

Of the three species described here $C$. adisi sp. nov. and C. nahvalr sp. nov. are the most similar, but C. adisi sp. nov. differs from C. nahvalr sp. nov. by: 
Table 2. Dates and collections of Columbianum adisi sp. nov. Key: arrow down = caught going down tree trunks; arrow up = caught going up tree trunks; $\mathrm{K}$ = collected from Kempson extractors from soil.

\begin{tabular}{|c|c|c|c|c|c|c|c|c|c|}
\hline$\stackrel{3}{\stackrel{3}{E}}$ & 总 & 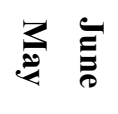 & $\overleftarrow{\Xi}$ & 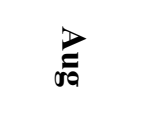 & $\stackrel{\mathscr{Q}}{=}$ & 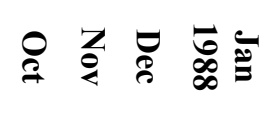 & 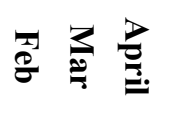 & $\stackrel{3}{2}$ & $\bar{\Xi}$ \\
\hline Trap type & $\downarrow$ & & $\downarrow$ & & $\mathrm{K}$ & $\mathrm{K}$ & K $\mathrm{K}$ & $\mathrm{K} \uparrow$ & $\downarrow$ \\
\hline No. specimens & 2 & & 16 & & 3 & 3 & 21 & 1,2 & 3 \\
\hline Condition & Inundated & & & Terrestrial & & & & Inundated & \\
\hline
\end{tabular}

- smaller body size (overall length, head width and rostrum to antennal length)

- thinner body for the number of tergites

- more regular tubercles on the pro- and metazonites, also including tubercles that resemble anchors in lateral view. Note however that this could be due to the state of preservation of the specimens looked at or perhaps a function of age/damage during life?

- posterior margin to pleurites with very strong saw-like edge (the angle in which this is viewed is critical)

- tergites shorter in adisi, and with prozonite shorter relative to metazonite

- collum anterior margin less V shaped in adisi

In addition, $C$. adisi sp. nov. lives in a different location - mixed water inundation forest rather than secondary upland forest.

\section{Comments on ecology}

Specimens of $C$. adisi sp. nov. were only found at Lago Janmauri which is a mixed water site described by Amaral et al. (1997) that is seasonally flooded by river water. They were collected using both Kempson extractors, which sample the soil invertebrates, and arboreal trunk traps that sample the fauna walking up or down trees (for more details of traps see Adis 2002). Specimens were caught on trunk traps placed on Hevea spruceana (Spruce ex Benth.) Müll.Arg. or rubber tree (Euphorbiaceae), and Virola surinamensis (Rol. ex Rottb.) Warb. (Myristicaceae), with the majority caught on the Hevea. The experiment was designed to follow the movements of various invertebrates as the forest was flooded, see for example Morais et al. (1987) for more details. The distribution of $C$. adisi sp. nov. in different samples is given in Table 2. From this it can be seen that the species appears to spend that part of the year when the forest is not inundated in the soil. Once flooding starts it moves onto the trees where it seems to live for the remaining part of the year. The largest sample was in July 1987 when 16 individuals were caught moving down the tree trunks, presumably heading to the ground and the soil at the end of the inundation period. Most of the individuals from the Kempson extractors were very small, suggesting that the eggs are laid in the forest litter or soil and the youngest stages pass their life here.

J. Adis (pers. com., 1994) noted that the mixed water forest is regarded as an ecotone between the black and white water inundation forests and that 'the species should represent in part those occurring in the black water forest at Taruma Mirim'. Columbianum nahvalr sp. nov. was found in the secondary, noninundated forest at Tauma Mirim. 


\section{Concluding remarks}

The siphonophorids have a reputation for being difficult to study, and that has been borne out by the current study. While the genus Columbianum seems to be well defined by the shape of the head and rostrum, it has been difficult to find other, reliable characters to distinguish clearly between species, and there is considerable variation within species and even individuals. More information about the postembryonic development might help evaluate the reliability of some of those discussed here.

\section{Acknowledgements}

This project would simply not have been possible without the help and encouragement of the late Joachim Adis (1950-2007) with whom we are very fortunate to have collaborated. Work in Plön (by HR) was supported by the Max-Planck-Institute für Limnologie (Plön), and she is grateful to all those that assisted during her stay. Work in Copenhagen (by HR) was supported by a grant from the European Commission's (FP 6) Integrated Infrastructure Initiative programme SYNTHESIS (DK-TAF). Sergei Golovatch and Hans Reip assisted greatly with literature, and Sergei Golovatch provided information that helped enable some ecological remarks. Florin Feneru and Chris Raper from the Angela Marmont Centre of the Natural History Museum in London assisted with some of the photographs. HR would also like to thank the late Steve Hopkin (1956-2006) for assistance at an early stage in this work and Mark Frater for continual encouragement.

\section{References}

Adis J. 2002. Recommended sampling techniques. In: Adis J. (ed.) Amazonian Arachnida and Myriapoda: 555-576. Pensoft, Sofia/Moscow.

Amaral I.L. do, Adis J. \& Prance G.T. 1997. On the vegetation of a seasonal mixedwater inundation forest near Manaus, Brazilian Amazonia. Amazoniana 14 (3-4): 335-347.

Attems C. 1951. Revision systématique des Colobognata (Myriapodes Diplopodes) et description d'espèces nouvelles. Mémoires du Muséum national d'Histoire naturelle Série A, Zoologie 3 (3): 193231.

Carl J. 1944. K.W. Verhoeffs System de Siphonophoriden kritisch betrachtet. Revue Suisse de Zoologie 51: 253-265.

Chamberlin R.V. 1922. The millipeds of Central America. Proceedings of the United States National Museum 60 (8): 1-75.

David J.F. \& Couret T. 1983. Le développement post-embryonnaire en conditions naturelles de Polyzonium germanicum (Brandt) (Diplopoda, Polyzoniida). Les cinq premiers stades. Bulletin du Muséum national d'Histoire naturelle 4e série, section A, 5 (2): 585-590.

Enghoff H. 1982. The millipede genus Cylindroiulus on Madeira - an insular species swarm (Diplopoda, Julidae). Entomological Scandinavica Supplement 18: 1-142.

Enghoff H., Dohle W. \& Blower J.G. 1993. Anamorphosis in millipedes (Diplopoda) - the present state of knowledge with some developmental and phylogenetic considerations. Zoological Journal of the Linnean Society 109: 103-234. https://doi.org/10.1111/j.1096-3642.1993.tb00305.x

Jeekel C.A.W. 1971. Nomenclator generum et familiarum Diplopodorum: A list of the genus and family-group names in the Class Diplopoda from the $10^{\text {th }}$ edition of Linnaeus, 1758 , to the end of 1957. Monografieen van de Nederlandse Entomologische Vereniging 5: i-xii, 1-412 [for 1970].

Jeekel C.A.W. 2001. A bibliographic catalogue of the Siphonophorida (Diplopoda). Myriapod Memoranda 3: 44-71. 
Morais J.W. de, Adis J., Berti-Filho E., Pereira L.A., Minelli A. \& Barbieri F. 1987. On abundance, phenology and natural history of Geophilomorpha from a mixedwater inundation forest in Central Amazonia (Chilopoda). Entomologica Scandinavica Supplement 51: 115-119.

Read H.J. \& Enghoff H. 2009. The order Siphonophorida - A taxonomist's nightmare? Lessons from a Brazilian collection. Soil Organisms 81 (3): 543-556.

Schmidt D. 1962. Über die taxionomische Wertigkeit von Strukturen des Metazonite-Hinterrandes bei Diplopoden. Senckenbergiana biologica 43: 65-80.

Schubart O. 1945. Diplopódos de Monte Alegre (Municipod de Amparo, Est. de São Paulo). Papéis avulsos do Departamento de zoologia São Paulo 6: 283-320.

Shelley R.M. 1996. A description of Siphonophora portoricensis Brandt (Diplopoda: Siphonophorida: Siphonophoridae), with a catalogue or ordinal representatives in the New World. Journal of Natural History 30: 1799-1814. https://doi.org/10.1080/00222939600771051

Verhoeff K.W. 1941. Versuch eines Siphonophoriden-Systems und geographisch-phylogenetische Beurteilung der Gonopoden. Zoologischer Anzeiger 134: 212-224.

Wolf H.G. \& Adis J. 1992. Genetic differentiation between populations of Neomachilellus scandens inhabiting neighbouring forests in Central Amazonia (Insecta, Archaeognatha). Verhandlungen des Naturwissenschaftlichen Vereins Hamburg (N.F.) 33: 5-13.

Manuscript received: 28 June 2018

Manuscript accepted: 27 September 2018

Published on: 20 November 2018

Topic editor: Rudy Jocqué

Desk editor: Pepe Fernández

Printed versions of all papers are also deposited in the libraries of the institutes that are members of the EJT consortium: Muséum national d'Histoire naturelle, Paris, France; Meise Botanic Garden, Belgium; Royal Museum for Central Africa, Tervuren, Belgium; Natural History Museum, London, United Kingdom; Royal Belgian Institute of Natural Sciences, Brussels, Belgium; Natural History Museum of Denmark, Copenhagen, Denmark; Naturalis Biodiversity Center, Leiden, the Netherlands; Museo Nacional de Ciencias Naturales-CSIC, Madrid, Spain; Real Jardín Botánico de Madrid CSIC, Spain; Zoological Research Museum Alexander Koenig, Bonn, Germany. 